\title{
Maraş 12: A Walnut Cultivar with Cluster-bearing Habit
}

\author{
Mehmet Sütyemez ${ }^{1}$ and Sakir B. Bükücü \\ Department of Horticulture, Faculty of Agriculture, University of Kahramanmaras \\ Sutcu Imam, Kahramanmaras, Turkey
}

\section{Akide Özcan \\ Afsin Vocational School, University of Kahramanmaras Sutcu Imam, Kahramanmaras, Turkey}

Additional index words. walnut, Juglans regia, walnut breeding, cultivars, Maraş 12, cluster bearing

Walnut (Juglans regia L.) is one of the most important fruit species in the world because it is rich in nutrients and elements, and is a high-quality wood. There is an increasing interest by consumers in eating walnuts, especially in Middle Eastern countries. Walnuts have favorable amounts of fatty acids, nutrients, and minerals. Anatolia is one of the originating centers of many fruit species, including the walnut (Juglans regia L.), which is a result, in part, of its unique geographic location, which brings about different types of climatic and edaphic conditions. Encountering a walnut tree in almost any part of Anatolia is a common experience, and many Anatolians are interested in walnuts as a local nut crop. The existing genetic diversity of walnuts in this area is very important for walnut breeders. To date, numerous walnut breeding studies have been carried out throughout the world (Akça et al., 2016; Germain, 1990, 1995; Vahdati et al., 2019). The general objectives of walnut breeding programs in many countries are to provide late-leafing cultivars with a high yield and a resistance to biotic and abiotic stresses. However, there has been a limited number of studies on the cluster-bearing habit in walnuts (Germain et al., 1997; Rezaee et al., 2006; Sutyemez, 1998; Vahdati et al., 2014). For this reason, our study evaluates the tree characteristics of the walnut cultivar Maraş 12, which has been registered in Turkey. 'Maraş 12' is a new walnut cultivar with a high number of nuts per cluster. This cultivar was released in 2016 by Kahramanmaraş Sütçü İmam University, Faculty of Agriculture, Kahramanmaraş province, Turkey (Anonymous, 2019). This walnut cultivar has a high estimated yield, with a nut weight of 9 to $12 \mathrm{~g}$ and a kernel weight of 5 to $7 \mathrm{~g}$.

Received for publication 17 May 2019. Accepted for publication 21 May 2019.

We acknowledge Prof. Dr. Kourosh Vahdati for the scientific editing of this article.

${ }^{1}$ Corresponding author. E-mail: sutyemez@ ksu.edu.tr.

\section{Origin}

'Maraş 12' was selected among a diverse range of genotypes in the Kahramanmaras province of Turkey in 1994 (Sutyemez, 1998, 2016; Sütyemez et al., 2018). To compare the performance of 'Maras 12' with 'Chandler', 10 replicates (i.e., scions) of both cultivars were grafted onto walnut rootstocks of the same age in 2001. The walnut breeding program was carried out at the University of Kahramanmaraş Sütçü İmam, Nut Application and Research Center (SEKAMER). The objective of this breeding program, which took from 1994 to 2018 , was to obtain promising cultivars characterized by important tree habits, nut traits, and resistance to some diseases.

\section{Description}

The aim of our research was to provide information on the new walnut cultivar Maraş 12. Here we report phenological and pomological traits according to the walnut descriptor and International Union for the Protection of New
Varieties of Plants (UPOV) (Anonymous, 1994, 2015). Data were collected for 4 years of observation (2015-18) on 10 'Maraş 12' and 10 'Chandler' trees.

Phenological evaluation. 'Maraş 12' is an early-season cultivar; its leafing date is about 3 weeks earlier than 'Chandler'. In general evaluations, 'Maraş 12 ' tends to initiate the growth of leaves before other established cultivars in the season. In comparison with 'Chandler', 'Maraş 12' shows an earlier blooming of its male and female flowers. Both types of flowers bloom simultaneously (which indicates homogamy). Nonetheless, the aim of this article is to emphasize the cluster-bearing habit of 'Maraş 12' as its most important trait (Fig. 1). The clusters of the female flowers in 'Maraş 12' can be comprised of up to 21 flowers, leading to a high estimated yield.

The abundance of female flowers in 'Maraş 12' is heavy, and catkin abundance is intermediate. About $80 \%$ to $85 \%$ of the lateral buds turn out to be fruitful. 'Maraş 12' is generally harvested toward the second week of September in the Kahramanmaraş region. 'Maraş 12' fruits mature about 1 month earlier than 'Chandler'. Its defoliation date is generally about 3 weeks earlier than that of 'Chandler' (Table 1).

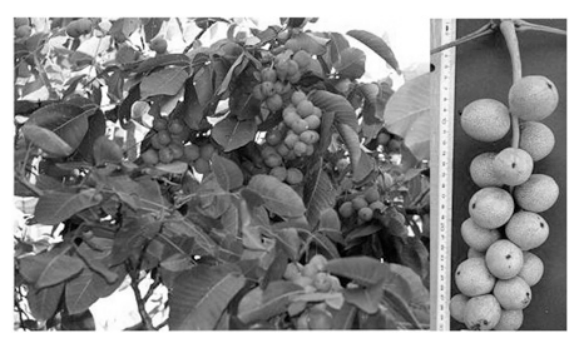

Fig. 1. A tree view of 'Maraş 12' at full-yield stage.

Table 1. Average phenological and pomological traits of 'Maras 12' compared with the standard 'Chandler' cultivar during 4 consecutive years.

\begin{tabular}{|c|c|c|c|}
\hline Characteristics & Maraş 12 & Chandler & References \\
\hline Leafing date & 23 Mar. & 12 Apr. & Sutyemez (1998) \\
\hline Harvest date & 11 Sept. & 5 Oct. & Anonymous (1994) \\
\hline Defoliation date & 11 Nov. & 30 Nov. & Anonymous (1994) \\
\hline First male bloom date & 31 Mar. & 12 Apr. & Anonymous (1994) \\
\hline Last male bloom date & 10 Apr. & 20 Apr. & Anonymous (1994) \\
\hline First female bloom date & 6 Apr. & 22 Apr. & Anonymous (1994) \\
\hline Last female bloom date & 18 Apr. & 7 May & Anonymous (1994) \\
\hline Dichogamy & Homogamy & Protandry & Anonymous (2015) \\
\hline Catkin abundance & Intermediate & Heavy & Anonymous (1994) \\
\hline Lateral bud flowering (\%) & $80-85$ & $90-95$ & Anonymous (1994) \\
\hline Female flower abundance & Intermediate & Heavy & Anonymous (1994) \\
\hline Flowers (no. per cluster) & $>21$ & $3-4$ & Anonymous (2015) \\
\hline Fruit set type & Cluster lateral & Lateral & Anonymous (2015) \\
\hline Estimated yield & High & High & Anonymous (1994) \\
\hline Nut shape & Ovate & Ovate & Anonymous (1994) \\
\hline Shell texture & Very smooth & Smooth & Anonymous (1994) \\
\hline Shell color & Very light & Light & Anonymous (1994) \\
\hline Shell strength & Weak & Weak & Anonymous (1994) \\
\hline In-shell nut weight (g) & $9-12$ & $12-14$ & Anonymous (1994) \\
\hline Kernel weight (g) & $5-7$ & $6-7$ & Anonymous (1994) \\
\hline Kernel percentage & $55-65$ & $48-51$ & Anonymous (1994) \\
\hline Kernel fill & Well & Moderate & Anonymous (1994) \\
\hline Ease of removal of kernel halves & Very easy & Very easy & Anonymous (1994) \\
\hline Kernel color & Light brown & Yellowish white & Anonymous (2015) \\
\hline
\end{tabular}




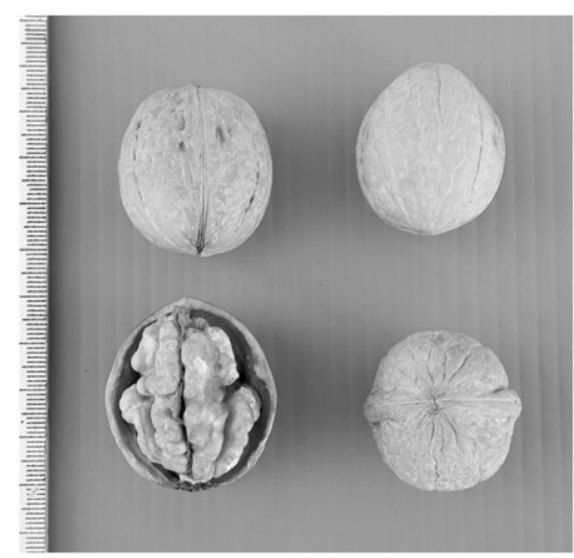

Fig. 2. A view of 'Maraş 12' nuts from different angles.

Pomological traits. The shape of the nuts is medium-size ovate. The shell of most nuts is weak, very smooth in texture, and very light in color. The kernel is very easy to remove. The kernels of 'Maras 12' are light brown (Fig. 2). By conducting measurements on 800 nuts during a period of 4 years, it was observed that each nut can weigh 9 to $12 \mathrm{~g}$, each kernel can weigh 5 to 7 $\mathrm{g}$, and kernel percentage is $55 \%$ to $65 \%$ (Table 1).

'Maraş 12' was registered and patented as a new walnut cultivar within the framework of walnut breeding regulations at the University of Kahramanmaraş, Sütçü İmam, Turkey. This cultivar is important because the fruitfulness of its cluster-bearing habit that, for this particular type, is comparable to other walnut cultivars. 'Maraş 12 ' can also be appreciated for its high fruit yield, which results in part from the existence of more than 21 flowers per cluster; good fruit quality; and early harvest and defoliation dates. These qualities are measurably distinct from other commercially grown cultivars in the world. 'Maraş 12 ' is recommended for regions where early spring frost is not a high risk of damage to flowers and fruit set.

\section{Availability}

Scions of 'Maraş 12' are available to walnut growers for grafting and, by appointment, can be collected from the Faculty of Agriculture, Kahramanmaraş Sütçü İmam University, Kahramanmaraş, Turkey.

\section{Literature Cited}

Akça, Y., M. Sütyemez, S. Yilmaz, and H. Karadag. 2016. The new walnut variety breeding program in Turkey, p. 461-466. In: Book of Proceedings, VII International Scientific Agriculture Symposium "Agrosym 2016". Jahorina, Bosnia and Herzegovina.

Anonymous. 1994. Walnut descriptors for walnut (Juglans spp.). International Plant Genetic Resources Institute, Rome, Italy.

Anonymous. 2015. Walnut guidelines for the conduct of tests for distinctness, uniformity and stability. International Union for the Protection of New Varieties of Plants, Geneva, Switzerland.

Anonymous. 2019. Meyve ve Asma Ceşit Listesi (Fruit Vine), Tescilli çeşitler listesi (Registered varieties). Republic of Turkey Ministry of Agriculture and Forestry Variety Registration and Seed Certification Center. 7 May 2019. $<$ https://www.tarimorman.gov.tr/BUGEM/ TTSM/Sayfalar/Detay.aspx? SayfaId=87>.

Germain, E. 1990. Inheritance of late leafing and lateral bud fruitfulness in walnut (Juglans regia L.), phenotypic correlations among some traits of the trees. Acta Hort. 284:125-134.

Germain, E. 1995. Genetic improvement of the Persian walnut (Juglans regia L.), p. 21-32. In: III International Walnut Congress 442.

Germain, E., F. Delort, and V. Kanivets. 1997. Precocious maturing walnut populations originating from central Asia: Their behavior in France. Acta Hort. 442:83-90.

Rezaee, R., W. Grigoorian, K. Vahdati, and M. Valizadeh. 2006. Evaluation of morphological traits associated with the vigor of Persian walnut seedlings. Iranian J. Hort. Sci. Technol. 7(3): $157-168$.

Sutyemez, M. 1998. Researches on walnut selection in Kahramanmaraş region and fertilization biology of selected genotypes. Cukurova University, Institute of Science, $\mathrm{PhD}$ Diss.

Sütyemez, M. 2016. New walnut cultivars: Maraş 18, Sutyemez 1, and Kaman 1. HortScience 51:1301-1303.

Sütyemez, M., A. Özcan, and Ş.B. Bükücü. 2018. Walnut cultivars through cross-breeding: 'Diriliş' and ' 15 Temmuz'. J. Amer. Pomol. Soc. 72(3):173-180.

Vahdati, K., M.M. Arab, S. Sarikhani Khorami, M. Sadat Hosseini, C.A. Leslie, and P.J. Brown. 2019. Advances in walnut (Juglans regia L.) breeding strategies. In: J.M. Al-Khayri, S.M. Jain, and D.V. Johnson (eds.). Advances in plant breeding strategies, Vol 4. Nut 139 and beverage crops. Springer, Switzerland.

Vahdati, K., D. Hassani, and R. Rezaee. 2014. Behavior of some early mature and dwarf Persian walnut trees in Iran. Acta Hort. 1050:189-196. 